\title{
The Role of Local Wisdom-based Student Worksheet on Scientific Reasoning
}

\author{
Noly Shofiyah \\ Science Education Study Program \\ Universitas Muhammadiyah \\ Sidoarjo \\ Indonesia \\ nolyshofiyah@umsida.ac.id
}

\author{
Enik Setiyawati \\ Science Education Study Program \\ Universitas Muhammadiyah \\ Sidoarjo \\ Indonesia \\ enik@umsida.ac.id
}

\author{
Nurdyansah \\ Science Education Study Program \\ Universitas Muhammadiyah \\ Sidoarjo \\ Indonesia \\ nurdyansyah@umsida.ac.id
}

\begin{abstract}
The aim of this research is to analyze the students' scientific reasoning skill by the use of Students' Local Wisdom-based Worksheet. This is a Quasi Experimental research with One Group Pre-test Post-test design. Research population are the entire students of science education of Universitas Muhammadiyah Sidoarjo. Thus, the sample is taken through purposive sampling, which are 4th semester students of science education department. This research utilizes Scientific Reasoning Test as the instrument. Acquired data then get analyzed in descriptive quantitatively by using $\mathrm{N}$-gain. In a brief, the findings show Students' Local Wisdom-based Worksheet has a moderate influence to the $\mathrm{N}$-gain value of 0,6 against the students' scientific reasoning skill.
\end{abstract}

Keywords—scientific reasoning, local wisdom, worksheet

\section{INTRODUCTION}

The characteristic of science learning might be distinguished into two. First, science learning is seen as a result of research from researchers. Second, science learning is seen as a research process from researchers in order to obtain a new knowledge [1]. In accord with the second perspective upon science learning, students should be taught on how to be able in discovering a fact, knowing an equation, and fact differentiation, as well as probing the connection between the acquired facts through an inquiry process. In other words, students are expected to master a scientific reasoning skill that might support them in answering issues within an investigation process.

Scientific reasoning is one of 21 century skill that is expected to be applied onto science class, aiming as an effort of students' preparation in engaging with globalization challenges [2]. Scientific reasoning is a decision making skill, in an outlined manner, according to the existing facts [3]. Through reasoning learning, students may utilize it as a provision for taking a decision in an outlined manner, which is complemented by the use of proper and clear language in explaining each concept from the acquired fact [4].
According to Karplus, scientific reasoning has two patterns, these are concrete scientific reasoning pattern and formal scientific reasoning pattern [5]. In order to attain formal scientific reasoning, the students ought to master the pattern of concrete scientific reasoning. The early test result about scientific reasoning, which was given towards the students of Science department, indicates that most of them has been in a concrete pattern, and only a small group of them that is in formal scientific reasoning pattern [6]. Thereby, a certain model or teaching material that may assists students in mastering the skill of scientific reasoning, specifically in formal pattern, is required. This thing is according to the theory proposed by Jean Piaget, which states that a students at the age around 17 above should have been able in forming a more complex reasoning operation as well as thinking abstractly [5].

One of the factors that becomes the cause of students' inability to reach their real potential is actually the fact that the students themselves aren't used in solving a problem related with scientific reasoning skills [6]. Several teachers has utilized practice method to teach scientific reasoning. However, the method that was used is not optimal since the problems presented are taken from several book references, whereas the problem itself is general in nature and unspecific in regard with students' surrounding environment [7]. In other words, another method or an application of teaching material by presenting local wisdom-based problems is required.

Teaching material has various types, be it printed or nonprinted. Printed teaching material that is frequently found among others in form of hand-out, book, module, brochure, and students' worksheet. Students' worksheet, is a teaching material that in such a way has been packed, so students are expected to comprehend the worksheet by themselves. In students' worksheet, students will get a material summary, and task that is related with the material. In this research, the developed students' worksheet will be based upon local wisdom, where the presented problems to be solved by students are taken from students' surrounding environment. Local wisdom may serves as learning stimulus to motivate and assist students in constructing knowledge [8] thus, students' scientific reasoning 
might develop. Marlina explained that scientific behavior of biology teacher candidate who use uses inquiry-based laboratory activity by utilizing local environment is significantly different compared to the use of traditional laboratory activity [9]. Dewi et al. also noted that the model of local wisdom-based learning through environment adaptation, the conservation values embedded within residents' social life are expected to nurture the skill of problem-solving, scientific communication, and caring attitude to preserve the environmental balance [10]. In addition, Yuenyong and Narjaikaew revealed that scientific literacy in Thailand could be developed by teaching science through incorporating the infusion of local wisdom into science learning [11].

According to the above explanation, this research is focused upon the implementation of local wisdom-based students' worksheet in order to develop students' scientific reasoning skills as an attempt that they who are teacher candidates may have scientific reasoning skills and influencing these skills towards the students, when they have become full-fledged teacher.

\section{METHOD}

This research is quasi-experimental type, due to research variables that later will resulting in quantitatively countable data. Aside from that, descriptive research is also employed to explain the data portrayals that were obtained in a more detailed manner. Research samples are $4^{\text {th }}$ semester students of science education of Universitas Muhammadiyah Sidoarjo, which amounted 16 students, and partaking the lecture of movement and change. This research is conducted on even semester, academic year of 2018/2019.

This research's design is using One Group Pretest-Posttest Design, which can be depicted into the following [12]:

$$
\begin{array}{|c|}
\hline \mathrm{O}_{1} \mathrm{X} \mathrm{O}_{2} \\
\text { Fig. 1. Research Design }
\end{array}
$$

With $\mathrm{O}_{1}$ is pretest (scientific reasoning test) that was given before the lecture with the implementation of local wisdombased students' worksheet. $\mathrm{O}_{2}$, states the given posttest prior to the lecture. $\mathrm{X}$ is the treatment that is in shape of learning by the application of local wisdom-based students' worksheet under the theme of "Salted Egg Production".

The acquired data then get analyzed by using the equation of normalized $\mathrm{N}$-gain in order to know the influence from the application of local wisdom-based students' worksheet against scientific reasoning skills.

$$
\langle g\rangle=\frac{S \text { post }-S \text { pre }}{S \text { max }-S \text { pre }}
$$

Symbol (S post) and (S pre) signify the average score of post-test and pre-test respectively. The value of $\mathrm{g}$ is described as follow: high if $\mathrm{g}>0,7$; moderate if $0,3 \leq \mathrm{g} \leq 0,7$; and low if $\mathrm{g}<0,3$ [13]. Aside from that, the result of scientific reasoning obtained by each individual was described in accordance with the criteria.

TABLE I. SCIENTIFIC REASONING TEST CRITERIA

\begin{tabular}{|c|c|}
\hline Score Interval & Scientific Reasoning \\
\hline $0 \%<\mathrm{P}<25 \%$ & Less Complex \\
\hline $25 \% \leq \mathrm{P}<50 \%$ & Quite Complex \\
\hline $50 \% \leq \mathrm{P}<75 \%$ & Complex \\
\hline $75 \% \leq \mathrm{P} \leq 100 \%$ & Very Complex \\
\hline
\end{tabular}

\section{RESULTS AND DISCUSSION}

Scientific reasoning test result depicts on how far students master the material of food preservation and scientific reasoning skills in producing qualified salted egg. The test was conducted twice, as pre-test before the students receiving treatment, and later at the following test after the implementation of local wisdom-based students' worksheet. The result of pre-test and post-test, as well as the $\mathrm{N}$-gain score analysis is presented into Table 2 . The obtained score depicted whether local wisdom-based students' worksheet influential towards students' scientific reasoning skills.

TABLE II. N-GAin SCORE OF STUdENTS SCIENTIFIC REASONING

\begin{tabular}{|c|c|c|c|c|}
\hline Students & Pre & Post & N-gain & Category \\
\hline $1^{\text {st }}$ & 45 & 75 & 0,5 & Moderate \\
\hline $2^{\text {nd }}$ & 60 & 95 & 0,9 & High \\
\hline $3^{\text {rd }}$ & 45 & 80 & 0,6 & Moderate \\
\hline $4^{\text {th }}$ & 45 & 85 & 0,7 & Moderate \\
\hline $5^{\text {th }}$ & 60 & 80 & 0,5 & Moderate \\
\hline $6^{\text {th }}$ & 55 & 90 & 0,8 & High \\
\hline $7^{\text {th }}$ & 55 & 80 & 0,6 & Moderate \\
\hline $8^{\text {th }}$ & 50 & 80 & 0,6 & Moderate \\
\hline $9^{\text {th }}$ & 35 & 70 & 0,5 & Moderate \\
\hline $10^{\text {th }}$ & 40 & 90 & 0,8 & High \\
\hline $11^{\text {th }}$ & 45 & 90 & 0,8 & High \\
\hline $12^{\text {th }}$ & 35 & 55 & 0,3 & Moderate \\
\hline $13^{\text {th }}$ & 30 & 60 & 0,4 & Moderate \\
\hline $14^{\text {th }}$ & 30 & 60 & 0,4 & Moderate \\
\hline $15^{\text {th }}$ & 50 & 90 & 0,8 & High \\
\hline $16^{\text {th }}$ & 55 & 80 & 0,6 & Moderate \\
\hline \multicolumn{2}{|c|}{ Average N-gain score } & $\mathbf{0 , 6}$ & Moderate \\
\hline
\end{tabular}

According to Table 2, it can be seen that the learning by associating science with local-wisdom, which in this case is through the application of students' worksheet "Salted Egg Production" has moderate effect in assisting student mastery towards the pattern of formal scientific reasoning. This happened because ethno-science-based classrooms has implications in bridging the gap between the learners and the world of reality [14]. Ethno-science helped students to reflect the scientific problems each society using scientific method to get better results [15]. Owusu-Ansah \& Mji argued that scientific knowledge and its methods of investigation cannot be separated from a people's history, cultural context and worldview [16]. 
Aside from that, students' formal scientific reasoning pattern for each indicator also might be observed on Table 3 and Fig. 2. As presented on the Fig. 2, it can be explained that students dominate formal scientific reasoning in theoretical reasoning, combinatorial reasoning, control variables, as well as probabilistic and correlational reasoning. Where these four indicators are included into very complex category. This fact is happened due to the trained students whose scientific reasoning skills were trained through the use of local wisdom-based students' worksheet. Through learning by using local wisdombased students' worksheet, students are encouraged to conduct scientific process skills, like formulating hypothesis, proposing and defining variable, deciding procedure, collecting data, discussing the analysis as well as drawing conclusions. All of these skills nurture the ability to think, work and behave scientifically as an important aspect within the development of science and technology, as well as to solve the problem in our daily life. Local wisdom-based students' worksheet is concentrated upon problem and case presentation. This thing is quite effective in giving the effect towards the growth of students' scientific reasoning. Popil stated that giving several cases in a learning activity is an effective method to promote the facilitation of active learning, assisting clinic problem, and encouraging students' scientific reasoning skills [17]. Through case study, students will begin to compare the data finding, making finding correlation, composing argument, and reviewing the issues until the conclusion is drawn [18].

TABLE III. SCIENTIFIC REASONING CATEGORY

\begin{tabular}{|c|c|c|c|c|}
\hline $\begin{array}{c}\text { Formal Scientific } \\
\text { Reasoning } \\
\text { Indicator }\end{array}$ & $\begin{array}{c}\text { Pre- } \\
\text { Test }\end{array}$ & Category & $\begin{array}{c}\text { Post- } \\
\text { Test }\end{array}$ & Category \\
\hline $\begin{array}{c}\text { Theoretical } \\
\text { reasoning }\end{array}$ & $44 \%$ & $\begin{array}{c}\text { Quite } \\
\text { complex }\end{array}$ & $86 \%$ & $\begin{array}{c}\text { Very } \\
\text { complex }\end{array}$ \\
\hline $\begin{array}{c}\text { Combinatorial } \\
\text { Reasoning }\end{array}$ & $44 \%$ & $\begin{array}{c}\text { Quite } \\
\text { complex }\end{array}$ & $84 \%$ & $\begin{array}{c}\text { Very } \\
\text { complex }\end{array}$ \\
\hline $\begin{array}{c}\text { Functionality and } \\
\text { Proportional } \\
\text { Reasoning }\end{array}$ & $33 \%$ & $\begin{array}{c}\text { Quite } \\
\text { complex }\end{array}$ & $59 \%$ & Complex \\
\hline Control variables & $63 \%$ & Complex & $86 \%$ & $\begin{array}{c}\text { Very } \\
\text { complex }\end{array}$ \\
\hline $\begin{array}{c}\text { Probabilistic and } \\
\text { Correlational } \\
\text { Reasoning }\end{array}$ & $47 \%$ & $\begin{array}{c}\text { Quite } \\
\text { complex }\end{array}$ & $78 \%$ & $\begin{array}{c}\text { Very } \\
\text { complex }\end{array}$ \\
\hline
\end{tabular}

Aside from that, Figure 2, also depicts that students' scientific reasoning in the indicator of functionality and proportional reasoning has the lowest score. The possible explanation for such fact is that most of the students are still having a trouble in interpreting functional correlation into the mathematic manifestation or conversely. Students have not be able in asserting mathematic equivalent into the application of functional correlation in daily life.

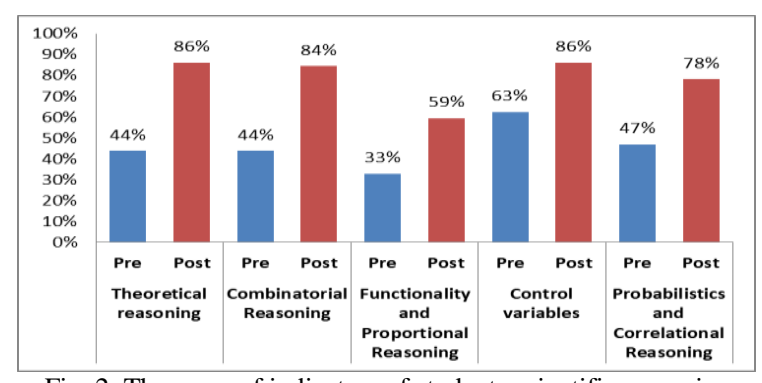

Fig. 2. The score of indicators of students scientific reasoning

In students' local wisdom-based student's worksheet, students are tasked to scientifically explain the phenomena or cases, which were found within the local wisdom of the local residents, specifically residents of Kebonsari village, district of Candi, Sidoarjo regency, which was nicknamed as Kampoeng Bebek and Salted Egg. The given explanation should be integrated with the material studied, so that there will be a linkage between science and local wisdom that existed in the surrounding environment. Before learning to use local wisdombased students' worksheet, students define salted eggs as "salted eggs". These answers are answers from common people, and are not scientific answers. After the implementation of the student's worksheet, the students are able to explain scientifically that salted eggs are eggs preserved using salt to create salty taste and also as an egg preservative. Salted eggs are foodstuffs that are liked and consumed by the community for side dishes to meet nutritional needs, especially protein adequacy. In addition, through the application of local wisdombased students' worksheet, students can determine how to get salted eggs with good quality based on organoleptic and physical properties. Factors that can affect the quality of salted eggs are the condition of the egg, the way it is salted, the taste of the egg, and the type of material.

This thing is corresponding against Holbrook's statement, that science will be more easily learnt when it makes a sense into students' perspective, and it is related with human environment, interest, as well as aspiration [19]. According to Nisa et.al. learning by using the ethno-science-integrated module within a problem-based learning may also give chances towards the students for directly get involved and active in science activity, as well as giving valuable experiences towards the students about science learning in a local wisdom context [20]. Due to that, the concept received by students will get easily remembered. Students will get more familiar with the material being learned.

\section{CONCLUSION}

Based upon this research's discussion, it can be concluded that the application of Students' Local Wisdom-based Worksheet under the theme of "Salted Egg Production" has a moderate influence in assisting students' mastery of their formal scientific reasoning aptitude. A suggestion for this research is the need of development for Students' Local Wisdom-based Worksheet with another theme that in match with the custom or tradition within the regions around Sidoarjo, 
for instance the production of Petis Ikan or Lumpur Lapindo cake making.

\section{ACKNOWLEDGMENT}

This research was supported by Universitas Muhammadiyah Sidoarjo.

\section{REFERENCES}

[1] B. Waldrip, V. Prain, and J. Carolan, "Using Multi-Modal Representations to Improve Learning in Junior Secondary Science," pp. 65-80, 2010.

[2] PISA, Take the Test: Sample Questions from OECD's Pisa Assessment, OECD, 2009.

[3] R. Steinberg and S. Cormier, "Understanding and Affecting Science Teacher Candidates' Scientific Reasoning in Introductory Astrophysics," vol. 020111, pp. 1-10, 2013.

[4] R. Wegerif, "Literature Review in Thinking Skills, Technology and Learning," 2007.

[5] R. Karplus, "Science Teaching and The Development of Reasoning," J. Res. Sci. Teach., vol. 14, pp. 169-175, 1977 .

[6] F. E. Wulandari and N. Shofiyah, "Problem-based Learning: Effects on Student's Scientific Reasoning Skills in Science," Int. Conf. Sci. Educ., 2018.

[7] B. Setiawan, D. K. Innatesari, and W. B. Sabtiawan, "The Development of Local Wisdom-Based Natural Science Module to Improve Science Literation of Students," J. Pendidik. IPA Indones., vol. 6, pp. 49-54, 2017.

[8] I. N. Suardana, Liliasari, and Ismunandar, "Peningkatan Penguasaan Konsep Mahasiswa Melalui Praktikum Elektrolisis Berbasis Budaya Lokal," J. Pendidik. dan Pembelajaran, vol. 20, pp. 45-52, 2013.

[9] R. Marlina, "Pemanfaatan Lingkungan Lokal dalam Kegiatan Laboratorium Berbasis Inkuiri terhadap Sikap Ilmiah Mahasiswa Calon Guru Biologi," pp. 1052-1060.
[10] I. N. Dewi, S. Poedjiastoeti, and B. K. Prahani, "Elsii learning model based local wisdom to improve students' problem solving skills and scientific communication," Int. J. Educ. Res., vol. 5, no. 1, pp. 107118, 2017.

[11] C. Yuenyong and P. Narjaikaew, "Scientific Literacy and Thailand Science Education," Int. J. Environ. Sci. Educ., vol. 4, no. 3, pp. 335349, 2009.

[12] J. R. Fraenkel, N. E. Wallen, and H. H. Hyun, How to Design and Evaluate Research in Education, 8th ed., New York: McGraw-Hill, 2004

[13] R. R. Hake, "Analyzing Change/Gain Scores," in American Educational Research Association, 1999, pp. 1-4.

[14] Okechukwu S. Abonyi, L. Achimugu, and M. I. Adibe, "Innovations in Science and Technology Education: A Case for Ethnoscience Based Science Classrooms," Int. J. Sci. Eng. Res., vol. 5, pp. 52-56, 2014.

[15] G. Boutte and G. L. Johnson, "Culturally Relevant Teaching in Science Classrooms: Addressing Academic Achievement, Cultural Competence, and Critical Consciousness," vol. 12, no. 2, pp. 1-20, 2010 .

[16] A. Owusu-Ansah, F.E., and Mji, "African indigenous knowledge and research,” African J. Disabil., vol. 2, pp. 1-5, 2012.

[17] I. Popil, "Promotion of Critical Thinking by Using Case Studies as Teaching Method," NEDT, vol. 31, pp. 204-207, 2011.

[18] R. Driver, N. Paul, and O. Jonathan, "Establishing the norms of scientific argumentation in classrooms," Sci. Educ., vol. 84, no. 3, pp. 287-312, 2000

[19] J. Holbrook, "Making Chemistry Teaching Relevant," Chem. Educ. Int., vol. 6, 2005 .

[20] A. Nisa, Sudarmin, and Samini, "Efektivitas Penggunaan Modul Terintegrasi Etnosains dalam Pembelajaran Berbasis Masalah untuk Meningkatkan Literasi Sains Siswa,” Unnes Sci. Educ. J., vol. 4, pp. 1049-1056, 2015 